\section{Global Change Media Briefings}

Environmental issues are, far too often, inherently controversial and lacking in simple solutions. How does one weigh the feasibility of building a dam to provide hydroelectric power against the possibility of destroying a river's fragile ecocomplex and its component ecosystems valued resources for generations? Or clear-cutting a forest to create farmland, resulting in the destruction of a natural habitat? Or importing hazardous waste to boost the local economy to the possible detriment of children's health?

Although most environmental issues, such as solid waste or water pollution, share some universality of nature, each nation and even each community has a unique perspective that needs to be addressed. SIPI's Global
Change Media Briefings provide a forum for in-depth discussion of the questions surrounding environmental controversies.

These briefings, featuring a panel of experts, present an opportunity for international and US journalists to learn about possible solutions to each other's environmental problems. Particular attention is paid to the dilemmas faced by developing nations.

\section{Roshi Pelaseyed, Director Global Change Program Scientists' Institute for Public Information 355 Lexington Avenue New York, NY 10017, USA.}

\title{
Royal Leadership and Awards for the Ageing
}

Age Resource and The National Council on Ageing, under the auspices of Age Concern England, are proud to announce that HRH The Prince of Wales has kindly agreed to be Age Resource's first President. Age Resource is a partnership between major organizations in the field of ageing and other nationally-known groups working in different areas through which the skills and experience of older people can make a valuable contribution. In such matters Britain once again stands out as something of a world leader.

The founding organizations include the two largest of their kind in the United Kingdom, namely the British Trust for Conservation Volunteers and the Royal Society for Nature Conservation. The Retired Executive Action Clearing House (REACH) and Shell UK are also participating.

\section{Origins and Objectives}

Age Resource came into being through the energies of a small group of people from Age Concern England and Shell UK, getting together with Robert Boote, CVO, first Director-General of the British Nature Conservancy Council. With an influential and committed group of patrons and under Robert Boote's energetic chairmanship, Age Resource believes that large numbers of older people have the will and enthusiasm, as well as the skills and ability, to contribute to society's environmental and conservational needs.

One of the initial schemes of Age Resource has been the setting up of three pilot projects - in Essex, Sussex, and Lancashire - to encourage the greater involvement of older people in environmental ventures, together with linked research and evaluation. A review of current and potential research activities is under way, with the collaboration of the Carnegie Inquiry into the Third Age, the Volunteer Centre UK, the Age Concern Institute of
Gerontology, REACH, and the Community Development Foundation.

When once Age Resource has become firmly established in Great Britain, it is hoped that it will be expanded across Europe, by which time its initiative should serve as a model for the rest of the world.

\section{Age Resource Awards}

Age Resource believes that 'you get out of life what you put into it', and so they have established the Annual Age Resource Awards (sponsored by Shell UK) to identify the enormous contribution which older people can, and in some cases do, make to life in the UK today. Last year the winners in its six categories inspired thousands of people, of 50 years of age or older, with their activity, enthusiasm, and often unique projects.

This year (1991) Age Resource extended the $£ 1,000$ Awards to nine categories covering three areas of Voluntary Work (Education, Caring, and Enhancing the Environment), as well as Personal Development, Selfhelp in the Community, Intergenerational Activity (schemes which bring together older and younger people for their mutual benefit), Campaigning, and Employment, the ninth Award being an open category which involves schemes that do not fit into anything else and thus completes some coverage of just about everything!

The closing day for this year's competition has passed but it is hoped to extend the scheme still further in 1992 and hold the award-winning ceremony again at the Royal Festival Hall in London.
ENID IRVING, Editor
Age Resource Newsletter
National Council on Ageing
Astral House, 1268 London Road
London SW16 4ER
England, UK.

\section{Circumpolar 'Ecosystems' in Winter}

On Friday, 16 February 1990, much confusion resulted from weather delays in Vancouver and Toronto. The travel people at North Star Tours managed to delay the Winnipeg-Churchill flight in order to pick up stragglers coming out of Toronto and elsewhere. However, those people who were many hours late getting into Winnipeg (flying with that other airline) were flown to Thompson and placed on a waiting train to Churchill. These problems were anticipated in advance (as we had planned for northern weather problems) and thanks to North Star, Canadian Airlines, and VIA Rail, we managed to keep running smoothly.
The Symposium got under way with a tour of CNSC and the 'Sundown Walkabout' during one of the warmest days that week, a balmy $-34^{\circ} \mathrm{C}$ with a wind-chill equivalent to somewhere near double this value $\left(-70^{\circ} \mathrm{C}\right)$. During the Walkabout there was a full-dress display ranging from seal and caribou (Rangifer $\mathrm{sp}$.) all the way to synthetics. The two Arctic Foxes (Alopex lagopus) that came on the Walkabout with us insisted on staying for dinner as well. While we struggled through our Char (Salvelinus alpinus) dinner with Manitoba Wild Rice (Zizania palustris) and French wines, the Centre managed to sell 86 tickets for a draw including Kaufman Sorel 
boots rated to $-65^{\circ} \mathrm{C}$ and Wind River apparel including a down parka. The proceeds go to the library fund at CNSC. After dinner we were entertrined by Rick Riewe, who contrasted strategies of Eskimo living in the most southerly community (Eskimo Point) with those living in the most northerly community (Griese Fiord).

On Saturday, we delayed the start of talks until 1:00 pm to allow for the 'train gang' to arrive and settle in at the CNSC. In all, about $30-45$ people attended throughout the weekend, depending on the event. In the middle of a full arctic blizzard (with temperature and windspeed off their respective scales) on Sunday alfternoon the valiant NRC staff cleared the $18 \mathrm{~km}$ road to Churchill and we bussed into the town movie theatre for a public showing of Inuit (Eskimo) fashions by Jill Oakes. We also toured the 'Complex' as the 'Modern Man' aspect of the 'Man in Winter' theme of the Workshop. After an early return to the CNSC, the question arose: How many blocks did Buster Welch use in making his igloo over the lunch hour? And while the igloo was within $100 \mathrm{~m}$ of the building, it took several expeditions to find all of the outfits that were looking for the igloo!

The workshop focused on igloo building on Monday, with instruction and much humour provided by Buster Welch and Rick Riewe. However, we did manage to complete 5 more passable igloos by sundown. Johan Tast was surprised to find that the yellow glow at the foot of the igloo in the morning was not the sunrise but was in fact yellow snow of obvious origin. And although vehemently denied by G.P. Kershaw, certain vigilantes aided by the local Arctic Fox population avenged Johan on the subsequent evening. On Tuesday, we were visited by a joint flock (herd?) of Willow and Rock Ptarmigan
(Lagopus lagopus and L. mutus, respectively) on our way off to the 'Walk Across the Continental Treeline'. We found considerable evidence of Snowshoe Hares (Lepus americanus) that were sleeping under Larch (Larix laricina) trees in the forest. We were hosted at Parks Canada by a notable Cree Interpreter who gave us an overview of 'Historic Man in Winter', highlighting our visit with the story of the Polar Bear in the beer hall. We were then hosted by the entire high-school where we took part in a panel discussion on various topics from global change to fish pollutants.

These are just a few of the many events and highlights of the first winter symposium. I say 'first' because I think there was unanimous recommendation for a second symposium at Churchill during 1992. Most people commented that the first event was not long enough and that the strong community support was very impressive. There are those participants who felt that the 1992 could not possibly top the 1990 Symposium. However, Dennis Macknak, Director of CNSC, has taken up the challenge. We already have a commitment for a genuine Finnish sauna to be built by Johan Tast for the next meeting, and a sub-marine demonstration by Buster Welch has been threatened as well. There are also plans in the works to allow people to make their own skin clothing which could be used while building their own igloo to sleep in.

PETER A. SCOTT, Symposium Chairman
Churchill Northern Studies Centre (CNSC)
PO Box 610
Churchill
Manitoba ROB OEO
Canada.

\section{Ecological Research at the Indian Institute of Science: An Overview}

The Indian Institute of Science, established in 1909 under the British, is located in Bangalore in the State of Karnataka. Currently there are over forty departments/centres on the campus of 372 acres (150.6 ha). Most pertinent for readers of Environmental Conservation is the Centre for Ecological Sciences in the Faculty of Life Sciences, which was initiated in 1982 primarily for conducting field research. This Centre is the first of its kind in India and is supported by the Department of Environment and Forests of the Government of India. Convened by Professor Madhav Gadgil since 1984, this Centre has been actively conducting both fundamental and applied research in various fields of ecology - such as biological species diversity, large-mammal ecology, insect behaviour and sociobiology, human ecology, ecodevelopment, and mathematical modelling.

Field research on animal and plant communities including the flowering plants, insects, amphibians, birds, and larger mammals - in the Western Ghats has been the primary interest of this Centre. The impacts of vegetation changes and human intervention on these natural communities have been looked at intensively, and conservation plans have been prescribed by the Centre. The role that Man plays in shaping the individual ecosystems - and hence the entire ecocomplex - by his dependence on the available primary resources, has been the focus in human ecology.

Fundamental questions on the evolution of eusociality and theories such as kin selection, are being answered in the well-established insect behaviour and sociobiology laboratory. The Centre maintains a permanent 50hectares' plot in the Western Ghats at Mudumalai (southwest of Bangalore), where mammal interactions with vegetation and the dynamics of tropical forests are being continuously monitored. Ecodevelopment emphasizes the need for Man to improve his management of biological communities through revegetation and more prudent use than is currently practised of fuel, fodder, and other raw materials extracted from the natural ecosystems of the Western Ghats. Simulations and mathematical models in all the abovementioned fields are simultaneously being dealt with in this Centre.

Since 1985, doctoral students (1-3 per year) have been offered fellowships to work on problems including community ecology of birds, insect behaviour and sociobiology, plant phenology, human ecology, ecological history of landscapes, parasite-host relationships in large mammals, and ecosystem management. The centre has three well-equipped field stations in Sirsi, Kumta (both in northern Karnataka), and Mudumalai (Tamilnadu), to facilitate field research in the Western Ghats. The Centre entertains Indian as well as foreign visitors.

The Centre trains personnel for field research and ecosystem management through direct field courses and workshops. One of the most significant workshops conducted at the Indian Institute of Science by the Centre for Ecological Sciences was the First Asian School on Conservation Biology, held in December 1987. The event 